University of Nebraska - Lincoln

DigitalCommons@University of Nebraska - Lincoln

Papers in the Earth and Atmospheric Sciences Earth and Atmospheric Sciences, Department

10-1892

\title{
A New Habitat of the Black-Throated Rock Swift, Micropus melanoleucus
}

Erwin Hinckley Barbour

University of Nebraska-Lincoln

Follow this and additional works at: https://digitalcommons.unl.edu/geosciencefacpub

Part of the Earth Sciences Commons

Barbour, Erwin Hinckley, "A New Habitat of the Black-Throated Rock Swift, Micropus melanoleucus" (1892). Papers in the Earth and Atmospheric Sciences. 344.

https://digitalcommons.unl.edu/geosciencefacpub/344

This Article is brought to you for free and open access by the Earth and Atmospheric Sciences, Department of at DigitalCommons@University of Nebraska - Lincoln. It has been accepted for inclusion in Papers in the Earth and Atmospheric Sciences by an authorized administrator of DigitalCommons@University of Nebraska - Lincoln. 


\section{A New Habitat of the Black-Throated Rock Swift, Micropus Melano:eucus.}

As curator of the museum, I have just procured for the State University of Nebraska a set of bird-skins prepared during the past summer, among which are five skins that must be of interest to ornithologists. They verify the discovery made by Professor Lawrence Bruner of the University of Nebraska, that the Whitethroated Rock Swift builds and breeds in the precipitous bluffs around Squaw Canon, Sioux Co., Nebraska, and, what is more likely, throughout the Pine Ridge regions, as Professor Bruner has observed them also at Crow Butte, near Crawford, Nebraska.

This isolated habitat of the White-throated Rock Swift, Micropus Melanoleucus (Panyptila Saxatilis), is several hundred miles east of its most eastern limits as known hitherto. Perhaps the Pine Ridge Buttes and bluffs, particularly those about Squaw Canon, are so admirably adapted to their nesting and high-flying habits as to be the attractive forces.

Although fire specimens were secured, no eggs were found. It should be mentioned, perhaps, that the egg of this swift is unknown. However, it is the expectation of the author that they will be found on some of his own, or some of the other numerous excursions sent annually to this excellent field by the university.

The nests are built high up in the cliffs, in the most inaccessible places. The semi-lithified sandstone of these buttes is easily excavated; and, as nearly as could be learned, the swifts dig back about eighteen inches, the opening barely admitting the hand but expanding somewhat at the nest. The nests are built of grass. 
As their early name implies, these swifts are all wings; accordingly the swiftness of their flight is such that the best shots make many misses and few hits. It took several rounds of ammunition for the five just added to the State collections. These specimens are all males, and inasmuch as their measurments differ slightly from published measurements, i. e., length 6.50-7.00 inches; extent, 14.00; they are given below for each bird:-

$\begin{array}{lccccc} & \text { No. 1. } & \text { No. 2. } & \text { No. 3. } & \text { No. 4. } & \text { No. 5. } \\ \text { Length, } & \mathbf{6} \frac{1}{2} & 6 \frac{3}{8} & 6 \frac{1}{2} & 6 \frac{3}{8} & 6 \frac{1}{4} \\ \text { Expanse, } & 14 & 14 \frac{1}{2} & 14 \frac{1}{8} & 14 \frac{8}{8} & 14\end{array}$

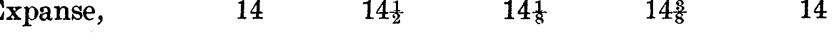

From the foregoing measurements it will be seen that, while the length is less, the expanse is greater than those published. These swifts were first observed by Professor Bruner while on a government entomological expedition in the summer of 18y1. At the direction of Professor Bruner his ornithological assistant, Mr. J. B. White, shot and prepared the above specimens this past summer. Being in charge of the Morrill geological expedition sent to this region by the University, I had occasion to fall in with Professor Bruner's party, and to observe these swifts personally. We must have seen several hundred at Squaw Canon flying in and out among the buttes which rise with nearly vertical walls five hundred to twelve hundred feet above the Hot Creek Basin.

Having occasion to visit this region several times annually with parties of students, it is to be hoped that we may obtain data for further notes, and that it may be possible to secure their nests and eggs, in spite of their inaccessible abodes.

\begin{tabular}{|c|}
\hline $\begin{array}{l}\quad \text { Reading Matter Notices. } \\
\text { Ripans Tabules : for torpid liver. } \\
\text { Ripans Tabules banish pain. }\end{array}$ \\
\hline 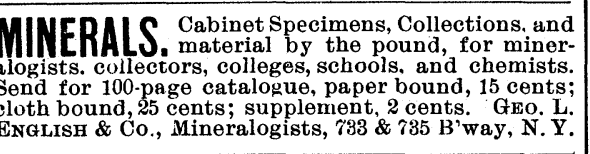 \\
\hline
\end{tabular}

THE LABRADOR COAST.

A JOURNAL OF TWO SUMMER CRUISES TO THAT REGION.

WITH NOTES ON ITS EARLY DISCOVERY, ON THE ESKIMO, ON ITS PHYSICAL GEOGRAPHY, GEOLOGY AND NATURAL HISTORY, TOGETHER WITH A BIBLIOGRAPHY OF WORKS, ARTICLES, AND CHARTS RELATING TO THE CIVIL AND NATURAL HISTORY OF THE LABRADOR PENINSULA.

By ALPHEUS SPRING PACKARD, M.D., Ph.D. Sportsmen and ornithologists will be interested in the list of Labrador birds by Mr. L. W. Turner, which has been kindly revised and brought down to date by Dr. J. A. Allen. Dr. Sflies, and Prof. John Macoun, of Ottawa, Canada, has prepared the list of Labrador plants.

Much pains has been taken to render the bibliog raphy complete, and the author is indebted to Dr. Franz Boas and others for several titles and important suggestions; and it is hoped that this feature of the book will recommend it to collectors of Ameri cana.

It is hoped that the volume will serve as a guide yachtsmen, sportsmen, artists, and naturalists, as well as those interested in geographical and historical studies.

$$
513 \mathrm{pp} ., 8^{\circ}, \$ 3.50 \text {. }
$$

N. D. C. HODGES, 874 Broadway, New York.

\begin{tabular}{|c|c|}
\hline Exchanges. & Wants. \\
\hline $\begin{array}{l}\text { For Exchan } \\
\text { Gray's Anate } \\
\text { in good condi } \\
\text { tel College, A }\end{array}$ & $\begin{array}{l}\text { METALLURGICAL CHEMIST will give instrue- } \\
\text { tion in the metallurgy and chemical analysis } \\
\text { of iron and steel. Complete or special courses ap- } \\
\text { plying to the manufacture of pig irons and steels, as } \\
\text { well as to their uses. Address "METALLU RGIST," } \\
\text { care SCIENCE. }\end{array}$ \\
\hline $\begin{array}{l}\text { For Sale or Exchange.-The subscriber would } \\
\text { like to receive cash offers, or an offer in exchange } \\
\text { for the earlier volumes of Poggendorf's Annalen } \\
\text { and the later volumes of Silliman's Journall upon } \\
\text { the following list: Chenn -Manuel de Conchylio } \\
\text { logiè. 2 vols. Nearly } 5,000 \text { figures, some hand-col- } \\
\text { ored. Paper. Paris, } 1859 \text {. Edwards. Butterflies } \\
\text { of N. A. 2 vols. Plates hand-colored. Vol. I., half } \\
\text { calf. Vol. II. in parts. Leyman, Agassiz, Hagen.- } \\
\text { Ills. Cat. Mus. Comp. Zool. at Harvard. No. I. }\end{array}$ & $\begin{array}{l}\text { W ANTED.-By well - qualified and experienced } \\
\text { science master and associate of the Royal } \\
\text { School of Mines, London, aged } 26 \text { (at present in } \\
\text { England), a mastership in technical college or uni- } \\
\text { versity for any of the following subjects: Engineer- } \\
\text { ing sciences, geology and mineralogy, physics, chem- } \\
\text { istry and metallurgy, etc., etc. Can provide excel- } \\
\text { lent references and credentials. Apply, J. G., } 17 \\
\text { Sussex St., Rochdale, England. }\end{array}$ \\
\hline $\begin{array}{l}\text { Ophiuridae. No. II., Acalephae. No. III., Astasidae. } \\
\text { All bound in one volume. American Naturalist. } \\
\text { Vols. I.-VII. Cloth. S1lliman's Am. Jour. of } \\
\text { Science and Arts. Third Series. Vols. I.-X. Cloth. } \\
\text { Binney.-Terrestrial Mollusks of N. A. Colored } \\
\text { plates. 4 vols. Stretch.-Zygaenidae and Bomby- } \\
\text { cidae of N. A. Colored plates. Also a considerable } \\
\text { library of monographs, reports, and scientific } \\
\text { books, and a large number of duplicates of fossils, } \\
\text { minerals and shells. E. A. STRONG, Ypsilanti, } \\
\text { Mich., Sept., 1892. } \\
\text { Exchange.-I have, the finest shells of Anodonta } \\
\text { corpulenta, C'p'r, and Suborbiculata, Say, in the }\end{array}$ & $\begin{array}{l}\text { ARADUATE of the University of Pennsylvania } \\
\text { and a practical mineralogist of twenty years' } \\
\text { experience desires to give his services and a cabi- } \\
\text { net of } 25,100 \text { specimens, all named, with about the } \\
\text { same number of duplicates, in minerals, crystals, } \\
\text { rocks, gems, fossils, shells, archæological and ethno- } \\
\text { logical specimens and woods to any institution de- } \\
\text { siring a fine outfit for study. The owner will in- } \\
\text { crease the cabinet to 50,000 specimens in two years } \\
\text { and will act as curator. Correspondence solicited } \\
\text { from any scientific institution. J. W. Hortter, } \\
\text { M.D., Ph.D., San Francisco, Cal., General P. O. } \\
\text { Delivery. }\end{array}$ \\
\hline $\begin{array}{l}\text { lso for exchange } 50 \text { varieties of fresh water al } \\
\text { and shells from Spoon River, Ill. DR. W. } \\
\text { TRODE, Lewistown, Ill. } \\
\text { To exchange for books on birds or insects, } \\
\text { o" baek volumes of American Naturalist " Ecke } \\
\text { Anatomy of the Frog," Packard's "Guide }\end{array}$ & $\begin{array}{l}\text { W ANTED. - A position as zoological artist in con- } \\
\text { rection with a scientific expedition, institution } \\
\text { or individual investigations. Experienced in micro- } \\
\text { scopic and all seientific work. References given if } \\
\text { desired. Address J. HENRY BLAKE, } 7 \text { Prentiss } \\
\text { Place, N. Cambridge, Mass. }\end{array}$ \\
\hline $\begin{array}{l}\text { 1yot's "The Earth and Man," Rockhill's, "The } \\
\text { nd of the Lamas," Parker's "Biology," Shoe- } \\
\text { aker's "Heredity, Health and Personal Beauty," } \\
\text { exter's "The Kingdoms of Nature," all new. M. J. }\end{array}$ & APMICT AND FNG \\
\hline
\end{tabular}

\section{The American Geologist for 1892.}

Edited by Prof. S. Calvin, University of Iowa; Dr. E. W. Claypole, Buchtel College; John Eyerman, Lafayette College; Dr. Prrsifor Frazer, Penn. Hort. Soc; ProF. F. W. Cragin, Colorado College; Prof. RoB'T T. HILl, U. S. Irrigation Survey; DR. ANDREW C. LAWson, University of California; R. D
SALISBURY, University of Wisconsin; JOSEPH B. TrRRELL, Geol. Sur. of Canada; E. O. UlRICH, Minnesota

Geological Survey: Prof. I. C. WhITE. University of West Virginia; PRoF. N. H. WINCHELL, University
of Minnesota. Now in its IXth volume. $\$ 3.50$ per year. Sample copies, 20 cents. Address 